\title{
Development of a real-time PCR system for the detection of the potential allergen fish in food
}

\author{
Carina Tetzlaff $^{1} \cdot$ Dietrich Mäde $^{1}$
}

Received: 30 May 2016 / Revised: 23 August 2016 / Accepted: 1 October 2016 / Published online: 13 October 2016

(C) The Author(s) 2016. This article is published with open access at Springerlink.com

\begin{abstract}
Fish is one of the most important triggers of food-allergic reactions. Regulation (EU) No 1169/2011 governs the labelling of allergenic ingredients including fish. A real-time PCR assay, using TaqMan ${ }^{\circledR}$ probes, was applied to detect fish in food. For generating primer and probes, the Hoxc13 gene was selected. Based on the alignment of available DNA sequences from this gene from different fish species in public nucleic acid database, specific oligonucleotides were generated. To cover all relevant species of the phylogenetic class fish, the CTfish-system consists of two forward primers, three reverse primers and one TaqMan ${ }^{\circledR}$ probe. The real-time PCR method is able to detect specifically fish species belonging to the subclass Teleostei. The sensitivity is in an animal food product $100 \mathrm{mg} / \mathrm{kg}$ and in a vegetable food matrix $10 \mathrm{mg} / \mathrm{kg}$ relating to the fresh weight. The calculated limit of detection $\left(\mathrm{LOD}_{95} \%\right.$ ) of fish DNA in background DNA is 2.5 copies. The method developed is robust against small, deliberate changes in the reaction conditions. The CTfish-system can be used to sensitively and selectively identify the presence of fish DNA in food.
\end{abstract}

Keywords Real-time PCR · Molecular detection · Fish · Allergy

\section{Abbreviations}

BHQ1 BlackHole ${ }^{\mathrm{TM}}$ Dark Quencher

ddPCR Droplet digital polymerase chain reaction

Dietrich Mäde

dietrich.maede@lav.ms.sachsen-anhalt.de

1 Landesamt für Verbraucherschutz Sachsen-Anhalt, Fachbereich 3 - Lebensmittelsicherheit, Freiimfelder Str. 68, 06112 Halle (Saale), Germany
FAM
6-Carboxyfluorescein
PCR Polymerase chain reaction
$\mathrm{R} \quad \mathrm{IUB}$ code for adenine or guanine
dsDNA Double-stranded DNA
Y IUB code for cytosine or thymin

\section{Introduction}

From the nutritional point of view, fish is a valuable food supplying the human with essential amino acids, lipid-soluble vitamins and $\omega-3$ fatty acids [1,2]. Besides its nutritional benefits, fish is as well one of the most important triggers of food-allergic reactions. The consumption of fish by affected persons may cause severe anaphylactic shocks with probably fatal consequences. Currently, about $0.1 \%$ of the population suffers from fish allergy and because of the increasing consumption of fishery products, the prevalence is rising [3]. Even small amounts of a few milligrams of protein can lead to allergic reactions immediately [4]. For this reason, the only possibility for affected persons is to avoid the intake of food containing allergens completely. To protect allergic persons, European legislation demands the obligatory labelling of 14 allergenic ingredients, including fish, by Annex II of Regulation (EU) No 1169/2011. The labelling obligations are required for consciously added ingredients only. Labelling thresholds are not defined yet in the European Union. On the other hand, hidden allergens can cause life-threatening reactions as well. Especially by "cross-contacts", resulting from contamination during production, storage or transport, allergenic substances can unintentionally get into products. Producers often use the optional labelling "may contain traces of...", which can cause uncertainty for allergic consumers. For this reasons, the development of specific and sensitive 
methods to detect the presence of fish in food is considered necessary. The German Federal Institute for Risk Assessment (BfR) specifies a limit of detection of 0.01-0.001\% for an allergenic ingredient in the final product for detection methods [5]. To define harmonised threshold values, the European Voluntary Incidental Trace Allergen Labelling (EU-VITAL) was developed. It establishes so-called action levels for the allergenic ingredients at which labelling is required [6].

For detection of fish allergens in food, enzyme-linked immunosorbent assay (ELISA) and polymerase chain reaction (PCR) technology are used most widely [7-11]. The majority of ELISA systems are based on the detection of the major fish allergenic protein, parvalbumin [8]. Compared to proteins, DNA is more stable against manufacturing processes. Besides this, molecular methods possess a better specificity than immunological methods [14].

The term "fish" is defined in EU legislation by the Regulation (EU) No 1379/2013. It refers to the Combined Nomenclature listing bony and cartilaginous fish. Most of the detection systems for fish available at present are specific for only a limited number of fish species, for specific allergens or use broadly reactive mitochondrial genes as target [9-13]. In this work, a real-time PCR system for the detection of all relevant species of fish which may be present in food products was developed. Single copy genes were used as target sequence to keep the possibility for molecular quantification.

\section{Materials and methods}

\section{Fish samples and food products}

The fish samples were obtained from fish farms, purchased on fish markets and supermarkets or were official samples. Food products used for spiking experiments were either purchased in local supermarkets or were sent in by local authorities as official samples for other diagnostic purposes. A summary of fish and food samples is shown in Table 1.

\section{Preparation of spiked samples}

To prepare mass fraction mixtures with different fish content, a serial dilution of fresh muscle meat $(10,000$, $1000,100,10,1,0.1,0.01 \mathrm{mg} / \mathrm{kg}$ ) from sample 260601 (Abramis brama) was done in the following food matrices: proteinshake powder and shrimp salad consisting of $245 \mathrm{~g}$ shrimps, $365 \mathrm{~g}$ pineapple and $477 \mathrm{~g}$ mayonnaise. The resulting spiked samples were homogenised in a mixer (Grindomix, Retsch, Haan, Germany). In addition, a serial dilution of fish DNA (20, 10, 5, 2, 1, 0.1 copies) from sample 260601 (Abramis brama) in background DNA of calves liver sausage $(c$ dsDNA $=20 \mathrm{ng} / \mu \mathrm{L})$ was made. The DNA copy number per microlitre of sample 260601 (Abramis brama) was determined by ddPCR (QX200 Droplet Generator and ddPCR Supermix for Probes, BioRad, München, Germany).

\section{DNA extraction}

The DNA was extracted using a modified CTAB method $[14,15]$. All DNA extractions were done in duplicates, using two portions of $200 \mathrm{mg}$ for each of the samples for extraction. To prevent cross-contamination, clean instruments were used for each sample. $1 \mathrm{~mL}$ CTAB-extraction buffer $[c(\mathrm{CTAB})=20 \mathrm{~g} / \mathrm{L}, c(\mathrm{NaCl})=1.4 \mathrm{~mol} / \mathrm{L}$, $c($ TRIS $)=0.1 \mathrm{~mol} / \mathrm{L}, c\left(\mathrm{Na}_{2}\right.$ EDTA $)=0.02 \mathrm{~mol} / \mathrm{L}, \mathrm{pH}$ 8.0] and $10 \mu \mathrm{L}$ Proteinase $\mathrm{K}$ solution $(c=20 \mathrm{mg} / \mathrm{L})$ were added to the sample. The samples were incubated at $60{ }^{\circ} \mathrm{C}$ under permanent agitation overnight and centrifuged for $10 \mathrm{~min}$ at $12,000 \times \mathrm{g}$ afterwards. The supernatant was transferred into a new vial. $0.7 \mathrm{~mL}$ of chloroform was added; the sample was shaken vigorously and centrifuged at $19,000 \times g$ for $10 \mathrm{~min}$. The upper phase was transferred into a new vial, and the volume was determined. Two volumes of CTAB precipitation buffer $[c(\mathrm{CTAB})=5 \mathrm{~g} / \mathrm{L}, c$ $(\mathrm{NaCl})=0.04 \mathrm{~mol} / \mathrm{L}]$ were added and incubated $60 \mathrm{~min}$ at room temperature without agitation. The samples were centrifuged for $5 \mathrm{~min}$ at $12,000 \times \mathrm{g}$, the supernatant was discarded, and the pellet was resuspended in $350 \mu \mathrm{L} \mathrm{NaCl}$ solution $[c(\mathrm{NaCl})=1.2 \mathrm{~mol} / \mathrm{L}] .350 \mu \mathrm{L}$ of chloroform was added; the samples were vigorously shaken and centrifuged for $10 \mathrm{~min}$ at $19,000 \times g$. The upper phase was transferred into a new vial; $0.6 \mathrm{vol}$ of isopropanol was added for nucleic acid precipitation. After 20-min incubation at room temperature, the samples were centrifuged for $10 \mathrm{~min}$ at $12,000 \times g$. The supernatant was discarded, the pellet was washed with $500 \mu \mathrm{L}$ ethanol solution $(c=70 \%)$, resolved in $100 \mu \mathrm{L} 0.1 \times \mathrm{TE}$ buffer [ $c$ (TRIS) $=1 \mathrm{mmol} / \mathrm{L}, c\left(\mathrm{Na}_{2} \mathrm{E}-\right.$ $\mathrm{DTA})=0.1 \mathrm{mmol} / \mathrm{L}, \mathrm{pH} 8.0]$ and stored as stock solution. $5 \mu \mathrm{L}$ of a tenfold dilution of the DNA stock solution was used as template for PCR.

The concentration and purity of the extracted nucleic acids were determined by measuring the optical density at 260 and $280 \mathrm{~nm}$ using a photometer (ScanDrop hotometer, Analytik Jena, Jena, Germany).

\section{DNA sequencing}

To verify the labelled species of the collected samples, the cytochrome $b$ gene was sequenced and species identification was done by comparing with the sequences in a public database $\left(\right.$ GenBank $^{\circledR}$ [16]). Additionally, the Hoxc13 genes of three samples 030915 (Raja brachyuran), 201001 
Table 1 Fish samples and food products used for method development. All fish samples were adjusted to a DNA concentration of about 1.8 ng/ $\mu \mathrm{L}$ based on photometric determination

\begin{tabular}{|c|c|c|c|}
\hline Trade name & Identified species & Sample number & $C \mathrm{q}$ (quantification cycle) \\
\hline Bream & Abramis brama & 260601 & $28.2 / 28.2$ \\
\hline Salmon & Salmo salar & 030901 & $28.7 / 28.6$ \\
\hline Rose fish & Sebastes norvegicus & 030902 & $29.1 / 29.3$ \\
\hline Saithe & Pollachius virens & 030904 & $30.5 / 31.2$ \\
\hline Red porgy & Pagrus spp. & 030905 & $30.2 / 30.6$ \\
\hline Nile perch & Lates niloticus & 030906 & $29.9 / 29.8$ \\
\hline Atlantic cod & Gadus morhua & 030907 & $27.4 / 27.4$ \\
\hline European seabass & Dicentrarchus labrax & 030908 & $29.9 / 29.5$ \\
\hline Atlantic halibut & Hippoglossus hippoglossus & 030909 & $32.4 / 32.4$ \\
\hline Brown trout & Salmo trutta & 030910 & $29.3 / 29.0$ \\
\hline European plaice & Pleuronectes platessa & 030911 & $29.2 / 28.9$ \\
\hline Tuna & Thunnus obesus & 030912 & $29.6 / 31.4$ \\
\hline Brook trout & Salvelinus fontinalis & 030913 & $24.6 / 24.5$ \\
\hline Monkfish & Lophius piscatorius & 030914 & $31.8 / 32.6$ \\
\hline Ray wings & Raja brachyura & 030915 & $37.3 / 40.2$ \\
\hline Wolffish & Anarhichas lupus & 030916 & $30.7 / 30.5$ \\
\hline Yellowtail amberjack & Seriola lalandi & 030918 & $28.1 / 28.5$ \\
\hline Atlantic herring & Clupea harengus & 080901 & $24.9 / 25.2$ \\
\hline Gilt-head bram & Sparus auratus & 080902 & $29.7 / 30.0$ \\
\hline Carp & Cyprinus carpio & 300901 & $28.2 / 28.4$ \\
\hline European perch & Perca fluviatilis & 300902 & $29.2 / 28.9$ \\
\hline Rainbow trout & Oncorhynchus mykiss & 300903 & $26.2 / 27.6$ \\
\hline Roach & Rutilus rutilus & 300904 & $29.3 / 30.3$ \\
\hline Sole & Solea solea & 041001 & $26.4 / 26.3$ \\
\hline Atlantic salmon & Salmo trutta fario & 041002 & $27.2 / 26.6$ \\
\hline Carp & Cyprinus carpio & 041003 & $30.6 / 29.6$ \\
\hline Lemon sole & Pleuronectes platessa & 041005 & $30.0 / 30.5$ \\
\hline Haddock & Melanogrammus aeglefinus & 041006 & $31.9 / 31.1$ \\
\hline European flounder & Platichthys flesus & 041007 & $29.5 / 29.6$ \\
\hline Turbot & Scophthalmus maximus & 041008 & $31.4 / 31.6$ \\
\hline European hake & Merluccius merluccius & 041009 & $30.3 / 29.8$ \\
\hline Ling & Molva molva & 041010 & $31.0 / 30.0$ \\
\hline Mullet & Liza ramada & 041011 & $31.6 / 32.1$ \\
\hline Wolffish & Anarhichas lupus & 041012 & $26.8 / 27.8$ \\
\hline Witch & Scophthalmus maximus & 041013 & $30.7 / 30.1$ \\
\hline Sea robin & Eutrigla gurnardus & 041015 & $30.2 / 31.1$ \\
\hline Weever & Trachinus draco & 041016 & $29.2 / 30.1$ \\
\hline Iridescent shark & Pangasianodon hypophthalmus & 091001 & $29.4 / 30.3$ \\
\hline Mackerel & Scomber scombrus & 161001 & $25.2 / 25.7$ \\
\hline Sprat & Sprattus sprattus & 161002 & $24.9 / 25.7$ \\
\hline Monkfish & Lophius piscatorius & 161004 & $29.2 / 28.9$ \\
\hline European pilchard & Sardina pilchardus & 161005 & $27.6 / 27.3$ \\
\hline Tilapia & Oreochromis niloticus & 161006 & $28.3 / 28.3$ \\
\hline Lump fish & Cyclopterus lumpus & 161007 & $32.5 / 31.9$ \\
\hline Dogfish & Squalus acanthias & 201001 & n.a./n.a. \\
\hline Meagre & Argyrosomus regius & 201002 & $28.0 / 28.1$ \\
\hline Catfish & Clarias gariepinus & 201003 & $28.8 / 28.7$ \\
\hline Zander & Sander lucioperca & 201004 & $31.2 / 31.9$ \\
\hline
\end{tabular}


Table 1 continued

\begin{tabular}{llll}
\hline Trade name & Identified species & Sample number & Cq (quantification cycle) \\
\hline Haddock & Melanogrammus aeglefinus & 201005 & $30.9 / 30.7$ \\
Northern pike & Esox lucius & 201006 & $31.0 / 31.2$ \\
Lake char & Salvelinus umbla & 201007 & $30.1 / 30.8$ \\
Eel & Anguilla anguilla & 231001 & $34.2 / 34.6$ \\
Tench & Tinca tinca & 231002 & $27.2 / 27.8$ \\
Blueblotch butterflyfish & Selaroides leptolepis & 261001 & $28.9 / 28.2$ \\
Sturgeon & Acipenser baeri & 250101 & n.a./n.a. \\
\hline Food & & Producer & \\
\hline Liver sausage of calves & Halberstädter GmbH, Halberstadt, Germany \\
Proteinshake powder & WellMix Sport, Dirk Rossmann GmbH, Burgwedel, Germany \\
Shrimptails & & SeaGold, Netto Marken-Discount AG and Co. KG, Marxhütte-Haidhof, Germany \\
Pineapple canned & Tip real-Handels GmbH, Düsseldorf, Germany \\
Mayonnaise & Tip real-Handels GmbH, Düsseldorf, Germany \\
\hline
\end{tabular}

n.a. no amplification

(Squalus acanthias) and 250101 (Acipenser baeri) were sequenced, using the sequencing-primers of the developed CTfish-system (see Table 3). In the following, differing reaction conditions for the Hoxc13 sequencing are located in brackets. PCR products of the cytochrome $b$ gene were generated using the primers $L 14735$ and H15149ad resulting in a PCR product of $464 \mathrm{bp}$ [17]. All oligonucleotides were synthesised by TIB MOLBIOL (Berlin, Germany). PCR products, which were applied in the subsequent sequencing reaction, were produced by using $1 \mu \mathrm{L}$ template in a total reaction volume of $25 \mu \mathrm{L}$. The reaction conditions were as follows: $2.5 \mu \mathrm{L} 10 \times$ PCR buffer containing $c\left(\mathrm{MgCl}_{2}\right)=15 \mathrm{mmol} / \mathrm{L}$ (Qiagen, Hilden, Germany), $3.5 \mu \mathrm{L} \mathrm{MgCl}_{2}\left[c\left(\mathrm{MgCl}_{2}\right)=25 \mathrm{mmol} / \mathrm{L}\right]$ (Qiagen, Hilden, Germany) resulting in a final concentration of $c\left(\mathrm{MgCl}_{2}\right)=5 \mathrm{mmol} / \mathrm{L}, 0.5 \mu \mathrm{L}$ dNTP-Mix [c (dATP, dCTP, dGTP, dTTP) $=200 \mu \mathrm{mol} / \mathrm{L}$ each] (Roche Diagnostics, Mannheim, Germany), $0.5 \mu \mathrm{mol} / \mathrm{L}$ of each primer and $0.025 \mathrm{U}$ thermostable Taq DNA polymerase (Hot Star Taq Polymerase, Qiagen, Hilden, Germany). Reactions were carried out on GeneAmp ${ }^{\circledR}$ PCR System 9700 thermal cycler (Applied Biosystems, Darmstadt, Germany) using an initial denaturation step for $15 \mathrm{~min}$ at $94{ }^{\circ} \mathrm{C}$, followed by 45 cycles of $30 \mathrm{~s}$ at $94{ }^{\circ} \mathrm{C}, 30 \mathrm{~s}$ at $58{ }^{\circ} \mathrm{C}($ Hoxc13: $\left.50{ }^{\circ} \mathrm{C}\right), 60 \mathrm{~s}$ at $72{ }^{\circ} \mathrm{C}$ and a final elongation step of $7 \mathrm{~min}$ at $72{ }^{\circ} \mathrm{C} .5 \mu \mathrm{L}$ of the PCR products was analysed on a $2 \%$ agarose gel in TAE buffer using a 100-bp fragment length marker (Gene Ruler ${ }^{\mathrm{TM}}$, Thermo Scientific, Waltham, USA). The remaining amount of the reaction volume was purified with the QIAquick ${ }^{\circledR}$ PCR Purification Kit (Qiagen, Hilden, Germany). The purified PCR products were sequenced with the BigDye ${ }^{\mathrm{TM}}$ Terminator V 1.1 Cycle Sequencing Kit (Applied Biosystems, Darmstadt, Germany) using the same primers as mentioned above. The reaction condition was as follows: $2 \mu \mathrm{L}$ Big Dye ${ }^{\circledR}$ Terminator V 1.1 V $3.15 \times$ Sequencing Puffer (Applied Biosystems, Darmstadt, Germany), $1 \mu \mathrm{L}$ Big Dye ${ }^{\circledR}$ Terminator V 1.1 Cycle Sequencing Kit (Applied Biosystems, Darmstadt, Germany), $0.5 \mu \mathrm{L}$ primer and $1-4 \mu \mathrm{L}$ template, depending on the intensity of the DNA band on the agarose gel. The samples were filled up with water to a total volume of $10 \mu \mathrm{L}$. Temperature and time conditions were as described above but using an annealing temperature of $55{ }^{\circ} \mathrm{C}$ (Hoxc13: $\left.48{ }^{\circ} \mathrm{C}\right)$. The PCR products were purified by ethanol precipitation. $1.3 \mu \mathrm{L}$ bromophenol blue, $10 \mu \mathrm{L}$ $3 \mathrm{M}$ sodium acetate [ $40.83 \mathrm{~g}$ sodium acetate per $100 \mathrm{~mL}$ water, $\mathrm{pH} 4.6], 90 \mu \mathrm{L}$ water, $250 \mu \mathrm{L} 10 \%$ (v/v) ethanol and the PCR product were mixed and incubated for $10 \mathrm{~min}$ at room temperature. Samples were centrifuged for $15 \mathrm{~min}$ at $12,000 \times g$, the supernatant was discarded, and the pellet was washed two times with $250 \mu \mathrm{L}$ ethanol solution $(c$ $(\mathrm{v} / \mathrm{v})=70 \%)$. After drying the pellet for $10 \mathrm{~min}$ at $65^{\circ} \mathrm{C}$, it was resolved in $20 \mu \mathrm{L}$ water and transferred into 0.5$\mu \mathrm{L}$ sample tubes (Applied Biosystems, Darmstadt, Germany). The analysis was carried out on an automated DNA sequencer (ABI Prism 310 Genetic Analyser, Applied Biosystems, Darmstadt, Germany). Resulting nucleic acid sequences were aligned with the help of Sequence Navigator software version 1.0.1 (Applied Biosystems, Darmstadt, Germany). The sequences were compared with sequences in GenBank ${ }^{\circledR}$ using the computer algorithm BLAST 2 [18]. 


\section{ddPCR}

The exact DNA copy number per microlitre in the DNA extract of sample 260601 (Abramis brama), used for the determination of the limit of detection, was determined by droplet digital PCR (ddPCR). A dilution series of three steps was analysed in four replicates. PCR products were produced by using $5 \mu \mathrm{L}$ DNA template in a total reaction volume of $20 \mu \mathrm{L}$. The reaction conditions were as follows: $10 \mu \mathrm{L}$ ddPCR Supermix for Probes (BioRad, München, Germany), $0.5 \mu \mathrm{mol} / \mathrm{L}$ of each primer and $0.2 \mu \mathrm{mol} / \mathrm{L}$ of TaqMan $^{\circledR}$ probe. Water was added up to a total amount of $20 \mu \mathrm{L}$. 9.5 $\mu \mathrm{L}$ of the mastermix and $5.64 \mu \mathrm{L}$ template were transferred into a cavity of a 96-well reaction plate and were mixed by repeated pipetting. The samples were centrifuged at $560 \times g$ for $2 \mathrm{~min}$, and the mix was aliquoted into two $20 \mu \mathrm{L}$ amounts and transferred into cavities of DG8 Cartridges for QX100/QX200 Droplet Generator (BioRad, München, Germany). $70 \mu \mathrm{L}$ Droplet Generation Oil for Probes (BioRad, München, Germany) was pipetted in the intended cartridges. Droplets were generated by a droplet generator (QX200 Droplet Generator, BioRad, München, Germany) and transferred into a 96-well reaction plate. The plate was sealed with foil (Pierceable Foil Heat Seal, BioRad, München, Germany) at $180{ }^{\circ} \mathrm{C}$ by a PX1 PCR Plate Sealer (BioRad, München, Germany). Reactions were carried out on GeneAmp ${ }^{\circledR}$ PCR System 9700 thermal cycler (Applied Biosystems, Darmstadt, Germany) using an initial denaturation step of $10 \mathrm{~min}$ at $95^{\circ} \mathrm{C}$, followed by 45 cycles of $30 \mathrm{~s}$ at $94{ }^{\circ} \mathrm{C}, 30 \mathrm{~s}$ at $60{ }^{\circ} \mathrm{C}$, and a final elongation step of $10 \mathrm{~min}$ at $98{ }^{\circ} \mathrm{C}$. The analysis was carried out by QX200 Droplet Reader (BioRad, München, Germany).

\section{Real-time PCR}

\section{Oligonucleotides}

The Hoxc13 gene was selected as target gene for real-time PCR. Sequence data were obtained from public database $\left(\right.$ GenBank $^{\circledR}$ [16]). Sequences of the Hoxc13 gene from seven different fish were checked theoretically for homologous sections using the computer program Clustal $\Omega$ [19]. The accession numbers of the selected sequences are given in Table 2. A region at the $5^{\prime}$ end was chosen as target region for primers and probes. Deviations of only single basepairs between the compared species were observed. The alignment is shown in Fig. 1. Based on sequence data, primer and probe sequences were generated for the real-time PCR with the help of the Primer Express ${ }^{\circledR} 2.0$ software (Applied Biosystems, Darmstadt, Germany). The received amplicon size is 141 or $134 \mathrm{bp}$ according to the different locations of the reverse primers. Based on five samples [030901 (Salmo salar), 080901 (Clupea harengus), 300901 (Cyprinus
Table 2 Hoxc13 genes with GenBank ${ }^{\circledR}$ accession numbers

\begin{tabular}{lll}
\hline Species & Scientific name & GenBank number \\
\hline Japanese rice fish & Oryzias latipes & AB_208012.1 \\
Herring & Clupea harengus & XM_012836065.1 \\
Guppy & Poecillia reticulata & XM_008413716.1 \\
Zebrafish & Danio rerio & NM_131543.1 \\
Tilapia & Oreochromis niloticus & XM_003448180.3 \\
Northern pike & Esox lucius & XM_010875284.1 \\
Salmon & Salmo salar & NM_001139531.1 \\
Cattle & Bos taurus & NM_001083490.1 \\
American alligator & Alligator mississippiensis & XM_006278444.1 \\
Clawed frog & Xenopus tropicalis & XM_002936645.3 \\
Chicken & Gallus gallus & XM_001235165.3 \\
\hline
\end{tabular}

caprio), 161006 (Oreochromis niloticus) and 201006 (Esox lucius)], the best primers and the best probe were chosen. These samples were amplified with the real-time PCR conditions described below using all possible primer combinations and one probe per reaction. By comparing the $\mathrm{Cq}$ values, the most sensitive primers and probe combinations were determined. All oligonucleotides shown in Table 3 were synthesised by TIB MOLBIOL (Berlin, Germany).

\section{PCR conditions}

Real-time PCRs were run in an ABI PRISM ${ }^{\circledR} 7900 \mathrm{HT}$ Sequence Detecting System (Applied Biosystems, Darmstadt, Germany) using an initial denaturation step for $10 \mathrm{~min}$ at $95^{\circ} \mathrm{C}$, followed by 45 cycles of $15 \mathrm{~s}$ at $95^{\circ} \mathrm{C}$ and $1 \mathrm{~min}$ at $60{ }^{\circ} \mathrm{C}$. The temperature, time conditions and ramp rate are optimised for this instrument in the $\mathrm{ABI}$ reaction cycle 9600 mode, which corresponds to a ramp rate of approximately $1{ }^{\circ} \mathrm{C} / 1 \mathrm{~s}$. All reactions were run in a reaction volume of $25 \mu \mathrm{L}$. The reaction conditions were: $12.5 \mu \mathrm{L}$ TaqMan $^{\circledR}$ universal real-time PCR Mastermix (Applied Biosystems, Darmstadt, Germany), $300 \mathrm{nmol} / \mu \mathrm{L}$ of each primer, $100 \mathrm{nmol} / \mu \mathrm{L}$ of the TaqMan ${ }^{\circledR}$ probe and $5 \mu \mathrm{L}$ template $(c$ dsDNA $=1.8 \mathrm{ng} / \mu \mathrm{L})$. The samples were brought up with water to a total volume of $25 \mu \mathrm{L}$.

\section{Validation}

\section{Determination of specificity and sensitivity}

The inclusivity of the PCR system was checked using $1.8 \mathrm{ng} / \mu \mathrm{L}$ template DNA of the fish samples. For testing the exclusivity, 1:10 dilutions of the extracted DNA of other animals [fly (Calliphora vicina), lobster (Homarus americanus), crocodile (Crocodylus niloticus), domestic duck (Anas sparsa), chicken (Gallus gallus), pigeon (Columba palumbu), mouse (Mus musculus), cattle (Bos 


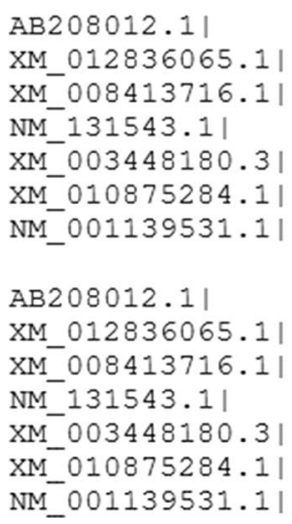

TTCGCTGGTTCTGCATCCACGCTGGGCGGACACCTTGATGTACGTTTATGAAAAAAGCCCG TTCGCTGGTCCTGCATCCATGCTGGGCGGACACCTTGATGTACGT GTATGAAAAAAGMCCG TTCGCTGGTTCTGCATCCACGCTGGGCGGACACCTTGATGTACGTTTATGAAAAAAGCCCG TTCGCAGGTCCTGCATCCACGCTGGGCGGACACCTTGATGTACGTGTATGAAAAAAGTCCG TTCGCTAGTTCTGCATCCACGCTGGGCGGACACCTTGATGTACGTTTATGAAAAAAGCCCG TTCGCTGGTTCTGCATCCACGCTGGGCGGACACCTTGATGTACGTTTACGAAAAAAGCCCG TTCÄCTGGTTCTGCATCCACGCTGGGCGGACACCTTGATGTACGTTTATGAAAAAAGCCCG

AATGAAAACAGCCAGAATAAAAGCCAAACAATGGAGGGACTGAGCGGTAATTGCCCTG AATGAAAATAATCCACATAAAAACCAATCCATGGAGGGACTAAGCGGGAATTGCCCCG AATGAAAGCAGCCAGAATAAAAGCCAAACAATGGAGGGACTGAGCGGTAATTGCCCTG AATGAAAATAATCAAAATAAAAGCCAAATTATGGAAGGATTGAGCGGGAATTGCCCTG AATGAAAACAACCAGAATAAAAGCCAAACAATGGAGGGACTGAGCGGTAATTGCCCTG AATGAAAATAATCCGAATAAAAGCCAAACAATGGAGGGACTGAGCGGGAATTGCCCGG AATGAAAATAATCCGAATAAAAACCAAACAATGGAGGGATTGAGCGGGAATTGCCCGG
Fig. 1 Homologues sequences of the Hoxc13 gene. The homologues sequences of the target gene sequences from Japanese rice fish, Herring, Guppy, Zebrafish, Tilapia, Northern pike and Salmon are aligned. The bases which are not homologous to the others are darkshadowed. The positions of the used primers are light-shadowed, and the probe sequence is framed

Table 3 Description of the used oligonucleotides

\begin{tabular}{|c|c|c|c|}
\hline Oligonucleotide name & Oligonucleotide sequence $\left(5^{\prime}-3^{\prime}\right)$ & Final concentration in PCR $(\mathrm{nmol} / \mu \mathrm{L})$ & References \\
\hline L14735 & 5'-AAA AAC CAC CGT TGT TAT TCA ACT A-3' & 500 & [16] \\
\hline H15149ad & 5'-GCI CCT CAR AAT GAY ATT TGT CCT CA-3' & 500 & [16] \\
\hline CTfish fwd1 & $5^{\prime}$-TTC GCT GGT TCT GCA TCC A-3' & 300 & This work \\
\hline CTfish fwd7 & 5'-TTC GCT GGT CCT GCA TCC A-3' & 300 & This work \\
\hline CTfish rev4 & $5^{\prime}$-CAG GGC AAT TCC CGC TCA AT-3' & 300 & This work \\
\hline CTfish rev6 & 5'-ATT ACC GCT CAG TCC CTC CAT-3' & 300 & This work \\
\hline CTfish rev7 & 5'-ATT CCC GCT TAG TCC CTC CAT-3' & 300 & This work \\
\hline CTSeq fwd & 5'-CGG CAR CCC STG ATA TG-3' & 500 & This work \\
\hline CTSeq rev1 & 5'-GAG CAD GGC TTC TGC TGC ARG TT-3' & 500 & This work \\
\hline CTSeq rev2 & 5'-GAA CAD GGT TTC TGC TGC ARG TT-3' & 500 & This work \\
\hline CTfish1 TMP & $\begin{array}{l}\text { 5'-FAM- ACA CCT TGA TGT ACG TTT ATG AAA AAA GCC } \\
\text { CGA-BHQ1-3' }\end{array}$ & 100 & This work \\
\hline
\end{tabular}

taurus), pig (Sus scrofa)] were amplified. The sensitivity was checked using $5 \mu \mathrm{L}$ of each dilution of the spiked products. PCRs were performed as described above. The limit of detection was tested using a serial dilution of fish DNA (Abramis brama) in background DNA extracted from food to mimic real sample conditions (calves liver sausage; $c$ dsDNA $=20 \mathrm{ng} / \mu \mathrm{L}$ ) in 12 replicates. The PCR was performed using $2.5 \mu \mathrm{L} 10 \times$ PCR buffer containing $c$ $\left(\mathrm{MgCl}_{2}\right)=15 \mathrm{mmol} / \mathrm{L}$ (Qiagen, Hilden, Germany), $0.5 \mu \mathrm{L}$ dNTP-Mix [c (dATP, dCTP, dGTP, dTTP) = $200 \mu \mathrm{mol} / \mathrm{L}$ each] (Roche Diagnostics, Mannheim, Germany), $2.5 \mathrm{U} /$ $\mu \mathrm{L}$ thermostable Taq DNA polymerase (Hot Star Taq Polymerase, Qiagen, Hilden, Germany), $300 \mathrm{nmol} / \mu \mathrm{L}$ of each primer, $100 \mathrm{nmol} / \mu \mathrm{L}$ of the TaqMan ${ }^{\circledR}$ probe and $5 \mu \mathrm{L}$ template. The samples were brought up with water to a total volume of $25 \mu \mathrm{L}$. The reaction was run in LightCycler $^{\circledR} 480$ (Roche, Mannheim, Germany) at the same temperature, time and ramp rate conditions as described above.

\section{Robustness}

The robustness of the method was checked by varying several parameters of the PCR reaction conditions like realtime instrument, $\mathrm{PCR}$ reagent kit, annealing temperature and primer and probe concentration. Table 4 lists the conditions used in the nine experiments. $5 \mu \mathrm{L}$ DNA extract of the sample of the $10 \mathrm{mg} / \mathrm{kg}$ fish-containing proteinshake powder, which correspondents to 20 copies per reaction, was used as template.

\section{Results and discussion}

\section{Specificity}

The specificity of the method was assessed in silico and by practical tests. The exclusivity was checked in silico 
Table 4 Conditions of the nine robustness experiments as orthogonal design

\begin{tabular}{lllllllllll}
\hline Factor & \multicolumn{7}{l}{ Combination } & & & \\
\cline { 2 - 9 } & 1 & 2 & 3 & 4 & 5 & 6 & 7 & 8 & 9 \\
\hline PCR equipment & $\mathrm{x}$ & $\mathrm{A}$ & $\mathrm{A}$ & $\mathrm{x}$ & $\mathrm{x}$ & $\mathrm{x}$ & $\mathrm{x}$ & $\mathrm{x}$ & $\mathrm{A}$ \\
PCR kit & $\mathrm{B}$ & $\mathrm{x}$ & $\mathrm{B}$ & $\mathrm{x}$ & $\mathrm{x}$ & $\mathrm{x}$ & $\mathrm{x}$ & $\mathrm{B}$ & $\mathrm{B}$ \\
Primer concentration $(\mathrm{nmol} / \mu \mathrm{L})$ & $\mathrm{x}$ & $\mathrm{x}$ & $\mathrm{x}$ & 360 & 240 & $\mathrm{x}$ & $\mathrm{x}$ & $\mathrm{x}$ & $\mathrm{x}$ \\
Probe concentration $(\mathrm{nmol} / \mu \mathrm{L})$ & $\mathrm{x}$ & $\mathrm{x}$ & $\mathrm{x}$ & $\mathrm{x}$ & $\mathrm{x}$ & 120 & 80 & $\mathrm{x}$ & $\mathrm{x}$ \\
Annealing temperature $\left({ }^{\circ} \mathrm{C}\right)$ & $\mathrm{x}$ & $\mathrm{x}$ & $\mathrm{x}$ & $\mathrm{x}$ & $\mathrm{x}$ & $\mathrm{x}$ & $\mathrm{x}$ & 58 & 62 \\
\hline
\end{tabular}

$\mathrm{x}=$ standard conditions, $\mathrm{A}=$ LightCycler $^{\circledR} 480$, Roche, Mannheim, Germany. B = HotStarTaq DNA Polymerase, Qiagen, Hilden, Germany

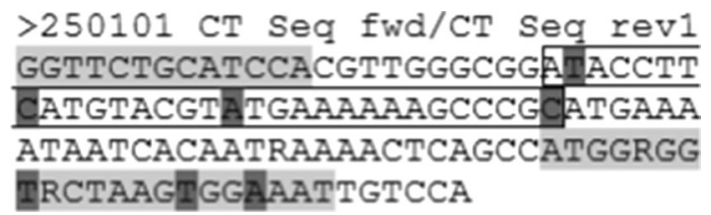

Fig. 2 Part of the Hoxc13-gene sequence of Sturgeon (250101). The bases which are not homologous to the CTfish-system are dark-shadowed. The positions of the primers are light-shadowed, and the position of the probe is framed

by comparing Hoxc13-gene sequences of animals belonging to other taxa than fish. The accession numbers of the selected sequences are given in Table 2. Practical evaluation was carried out by using DNA of different animals as template: fly (Calliphora vicina), lobster (Homarus americanus), crocodile (Crocodylus niloticus), duck (Anas sparsa), chicken (Gallus gallus), pigeon (Columba palumbu), mouse (Mus musculus), cattle (Bos taurus), pig (Sus scrofa). All results were negative, so false positive reactions by amplification of animals of other classes can be excluded. The primer-probe system consisting of CTfish1 TMP, CTfish fwd1, CTfish fwd7, CTfish rev4, CTfish rev6 and CTfish rev7 is specific for its target. The inclusivity was checked using 58 fish samples. The species was determined before by analysis of the cytochrome $\mathrm{b}$ gene. The results are shown in Table 1. Except for ray (030915), shark (201001) and sturgeon (250101) all tested fish species could be amplified with the primer probe system. To verify these results, the Hoxc13 gene of ray, shark and sturgeon was sequenced using the sequence-primers created of the CTfish-system. The DNA sequences of the ray and the shark sample showed no sufficient homology with the CTfish-system. The sequence of the sturgeon differs in three to four positions in the probe and the reverse primers, as presented in Fig. 2. These results confirm that the developed primer probe system is not able to amplify ray, shark and sturgeon. Ray and shark are cartilaginous fish (Condrichthyes). All other tested fish are bony fish (Osteichthyes) belonging to the Teleostei. Sturgeons represent an own subclass (Chondrostei). So the CTfish-system can be used to detect fish of the subclass Teleostei, which compromises the most commonly consumed food fish [20]. Further developments are required to enable the detection of other fish species.

\section{Sensitivity}

The sensitivity of the CTfish-system was determined with dilution series in two types of food: food of animal origin and food of non-animal origin. A premanufactured proteinshake powder and a laboratory-made shrimp salad were used as matrix for spiking experiments. In shrimp salad sensitivity of $100 \mathrm{mg} / \mathrm{kg}$ and in proteinshake powder a sensitivity of $10 \mathrm{mg} / \mathrm{kg}$ relating to the fresh weight were reached. The results are shown in Table 5. Calculated from the weight per haploid genome of Cyprinus caprio of about $1.9 \mathrm{pg}$ [21], the DNA content in white muscle meat of Cyprinus caprio of about $672 \mu \mathrm{g} / \mathrm{g}$ [22] and taking into consideration the extraction process, this approximately corresponds to 200 or 20 copies of the target gene.

The detection limit of allergens in food of 10-100 ppm as required by the German Federal Institute for Risk Assessment (BfR) was nearly reached. It has to be

Table 5 Sensitivity of the detection of fish in food matrices

\begin{tabular}{|c|c|c|c|c|c|c|c|}
\hline \multirow[t]{2}{*}{ Sample } & \multicolumn{7}{|c|}{ Content of fish (mg/kg) (calculated copy number based on $\mathrm{OD}_{260}$ in brackets) } \\
\hline & $10,000(20,000)$ & $1000(2000)$ & $100(200)$ & $10(20)$ & $1(2)$ & $0.1(0.2)$ & $0.01(0.02)$ \\
\hline Proteinshake powder ( $\mathrm{Cq}$ value) & $28.1 / 28.3$ & $31.3 / 31.6$ & $35.7 / 36.0$ & $39.6 / 40.0$ & n.a./n.a. & n.a./n.a. & n.a./n.a. \\
\hline Shrimp salad ( $C q$ value $)$ & $29.3 / 29.5$ & $32.7 / 32.4$ & $38.2 / 37.9$ & n.a./n.a. & n.a./n.a. & n.a./n.a. & n.a./n.a. \\
\hline
\end{tabular}

n.a. no amplification 
Table 6 Assessment of the limit of detection by using a dilution series in background DNA from food of Abramis brama

\begin{tabular}{llllllr}
\hline Theoretical copy number & 20 & 10 & 5 & 2 & 1 & $0: 1$ \\
\hline Number of PCR replicates & 12 & 12 & 12 & 12 & 12 & 12 \\
Number of positive test results & 12 & 12 & 12 & 10 & 10 & 1 \\
\hline
\end{tabular}

Table 7 Results of the robustness reactions using 20 copies per reaction in background DNA

\begin{tabular}{llllllllll}
\hline Combination & 1 & 2 & 3 & 4 & 5 & 6 & 7 & 8 & 9 \\
\hline Cq value & $36: 7 / 36: 7$ & $35: 6 / 34: 6$ & $33: 7 / 33: 8$ & $35: 8 / 35: 7$ & $37: 1 / 35: 7$ & $35: 8 / 36: 2$ & $37: 2 / 36: 6$ & $33: 6 / 33: 7$ & $35: 7 / 35: 4$ \\
\hline
\end{tabular}

considered that the proposed values are an average for all allergens. The EU-VITAL concept indicates individual detection limits for each allergen. A declaration of fish as ingredient is necessary at a content of $1.000 \mathrm{ppm}$ and the labelling "may contain traces of fish" at $100 \mathrm{ppm}$ [6]. The CTfish-system developed is capable of detecting these amounts of fish in food. A significant proportion of fish as allergen in food is co-processed with the original product. This could result in DNA degradation. Notwithstanding the PCR product, real-time PCR system is rather short and therefore the impact of processing should be limited; further experiments should be undertaken to verify the applicability to highly processed food. The limit of detection was determined using a dilution series of DNA copies in background DNA in twelve replicates. The results are shown in Table 6 . The limit of detection $\left(\mathrm{LOD}_{95 \%}\right)$ was calculated using the program Quodata [23]. LOD $_{95} \%$ is defined as the lowest concentration of fish DNA at which $95 \%$ of positive samples are detected [24]. With the PCR method, a $\mathrm{LOD}_{95} \%$ of 2.5 copies with a $95 \%$ confidence interval of 1.5-4.0 can be reached. According to Poisson statistics, the theoretically lowest achievable LOD $_{95} \%$ is three copies, which was reached [25]. The difference showing a better $\mathrm{LOD}_{95} \%$ than theoretically expected could be attributed to statistical bias. The requirement for a sensitive real-time PCR method is a $\mathrm{LOD}_{95} \%$ of less than 20 copies [24].

Overall, the CTfish-system can be classified as a sensitive real-time PCR method which fulfils all requirements for the limit of detection.

The ligation-dependent probe amplification developed by Unterberger et al. [11] reached a sensitivity similar to the CTfish-system. The limit of detection described was $20 \mathrm{mg} / \mathrm{kg}$ fish in spiked sushi. Compared to other PCR systems published, the developed method is less sensitive. Benedetto et al. [9] described a real-time PCR method to detect fish DNA in feedstuff based on the mitochondrial $12 \mathrm{~S}$ rRNA gene. With the primer-probe system generated, a limit of detection of $0.2 \mathrm{pg}$ fish DNA diluted in plant DNA could be reached. The higher sensitivity of the method based on $12 \mathrm{~S}$ rRNA can be attributed to the fact that each cell contains a lot of mitochondria and therefore several copies of target DNA. The number of mitochondria per cell and the DNA copies per mitochondria, however, is not constant but depends on the cell type and the individual. In the contrast to that, genomic genes are single copy gens, existing only one time per chromosome. Thus, the copy numbers detected correlate directly with the contained fish cells. These facts result in a subjective lower limit of detection compared to systems using mitochondrial genes. The advantage of this system, however, is the possibility to generate quantitative results. Another benefit of the developed real-time PCR system compared to the method of Benedetto et al. is that the CTfish-system can be used to detect fish in an animal DNA background.

\section{Robustness}

The robustness of a method is its capability to remain unaffected by small, randomly variations in the test conditions [24]. The altered variations comprising the type of instrument, the master mix, primer and probe concentration and annealing temperature are assessed by using an orthogonal design. The robustness test did not show any significant discrepancies (Table 7). The $\mathrm{Cq}$ values of the single reactions only vary slightly. It can be concluded that the CTfish-system is robust.

\section{Conclusion}

The developed real-time PCR method is able to detect the presence of organisms belonging to the Teleostei in food. Teleostei represent the largest group within the taxonomy of fish, containing most of the edible fish, and cover the economically relevant species. Further analyses may be required to enable also the detection of fish spices of minor importance, like sturgeons, sharks and rays (cartilaginous fish). The method fulfils all requirements concerning the specificity, the sensitivity and the robustness defined by the "Guidelines for the single-laboratory validation of 
qualitative real-time PCR methods" of the German Federal Office of Consumer Protection and Food Safety (BVL) [24].

\section{Compliance with ethical standards}

Conflict of Interest The authors declare that they have no conflict of interest.

Compliance with ethics requirements This article does not contain any studies with human or animal subjects.

Open Access This article is distributed under the terms of the Creative Commons Attribution 4.0 International License (http://creativecommons.org/licenses/by/4.0/), which permits unrestricted use, distribution, and reproduction in any medium, provided you give appropriate credit to the original author(s) and the source, provide a link to the Creative Commons license, and indicate if changes were made.

\section{References}

1. Oehlenschläger J, Rehbein H (2015) In: Fischer M, Glomb MA (eds) Moderne Lebensmittelchemie, 1st edn. Behr's, Hamburg

2. Belitz HD, Grosch W, Schieberle P (2012) Lehrbuch der Lebensmittelchemie, 6th edn. Springer, Berlin

3. Bugajska-Schretter A, Elfman L, Fuchs T, Kapiotis S, Rumpold H, Valenta R, Spitzauer S (1998) Parvalbumin, a cross-reactive fish allergen, contains IgE-binding epitopes sensitive to periodate treatment and Ca21 depletion. J Allergy Clin Immunol 1001:67-74

4. EFSA (2004) Opinion of the scientific panel on dietetic products, nutrition and allergies on a request from the commission relating to the evaluation of allergenic foods for labeling purposes. EFSA J 32:1-197

5. Bundesamt für Risikoforschung (2009) Stellungnahme Nr. 002/2010. http://www.bfr.bund.de/cm/343/bessere_allerngenkennzeichnung_von_lebensmitteln_fuer_verbraucher.pdf

6. EU-VITAL.ORG. http://www.eu-vital.org/de/konzept.html. Accessed 15 Mar 2016

7. Chen YT, Hsieh YH (2014) A sandwich ELISA for the detection of fish and fish products. Food Control 40:265-273
8. Fæste CK, Plassen C (2008) Quantitative sandwich ELISA for the determination of fish in foods. J Immunol Methods 329:45-55

9. Benedetto A, Abete MC, Squadrone S (2011) Towards a quantitative application of real-time PCR technique for fish DNA detection in feedstuffs. Food Chem 126:1436-1442

10. Herrero B, Vieites JM, Espiñeira M (2014) Development of an in-house fast real-time PCR method for detection of fish allergen in foods and comparison with a commercial kit. Food Chem 151:415-420

11. Unterberger C, Luber F, Demmel A, Grünwald K, Huber I, Engel KH, Busch U (2014) Simultaneous detection of allergic fish, cephalopods and shellfish in food by multiplex ligation-dependent probe amplification. Eur Food Res Technol 239:559-566

12. Dalmasso A, Fontanella E, Piatti P, Civera T, Rosati S, Bottero MT (2004) Multiplex PCR assay for the identification of animal species in feedstuffs. Mol Cell Probes 18:81-87

13. Sun M, Liang C, Gao H, Lin C, Deng M (2009) Detection of parvalbumin, a common fish allergen gene in food, by real-time polymerase chain reaction. J AOAC Int 92:234-240

14. Demmel A, Hahn A (2010) In: Busch U (ed) Molekular-biologische Methoden in der Lebensmittelanalytik. Springer, Berlin

15. Anonymous (2005) International Standard EN ISO 21571

16. http://www.ncbi.nlm.nih.gov/nucleotide. Accessed 01 Mar 2016

17. Anonymous (2008) Landesamt für Verbraucherschutz SachsenAnhalt, Prüfmethode Nr.15.0023.02 Nachweis der Fischart durch PCR-RFLP und Sequenzanalyse

18. http://blast.ncbi.nlm.nih.gov/Blast.cgi. Accessed 01 Mar 2016

19. http://www.ebi.ac.uk/Tools/msa/clustalo/. Accessed 01 Mar 2016

20. Fischinformationszentrum (2014) http://www.fischinfo.de/ images/broschueren/pdf/FIZ_DF_2014.pdf. Accessed 20 Feb 2016

21. http://www.genomesize.com. Accessed 01 Mar 2016

22. Rehbein H, Oehlenschlager J (eds) (2009) Fishery products: quality, safety and authenticity, 1st edn. Wiley, Oxford

23. https://quodata.de/content/validation-qualitative-pcr-methodssingle-laboratory. Accessed 18 Feb 2016

24. Bundesamt für Verbraucherschutz und Lebensmittelsicherheit (2016) Guidelines for the single-laboratory validation of qualitative real-time PCR methods. http://www.bvl.bund.de/SharedDocs/Downloads/09_Untersuchungen/Guidelines\%20for\%20 the \%20single\%20laboratory.pdf?_blob=publicationFile\&v $=2$

25. Uhlig S, Frost K, Colson B, Simon K, Mäde D, Reiting R, Gowik P, Grohmann L (2015) Validation of quantitative PCR on the basis of mathematical-statistical modelling of the probability of detection. Accred Qual Assur 20:75-83 